\title{
Performance Evaluation of Liquidity Position of Sugar Industry in Karnataka State
}

\author{
Dr.Salma Banu \\ Assistant Professor, Dept of Commerce \&amp; Management, UCA, TUT \\ DOI: 10.29322/IJSRP.12.01.2022.p12108 \\ http://dx.doi.org/10.29322/IJSRP.12.01.2022.p12108
}

\begin{abstract}
The adequate liquidity position of a concern shows the ability to manage day-to-day operations in the business. The study attempts to evaluate the current assets, current liabilities, liquid assets and liquid liabilities etc. to assess the liquidity position as well as solvency position of select sample sugar factories in Karnataka state. The study is also interested in applying the various statistical tools to arrive at the conclusion.
\end{abstract}

Index Terms- Liquidity, Current Assets, Current Liabilities, Precautionary Motive, Transaction Motives, Speculative Motive, Cash.

\section{INTRODUCTION}

L iquidity is abilityof the firm to convert its short term sources into cash.In order to manage day to day operations of the business, liquidity plays an important role.But adequate liquidity is desired for the performance of a business and excessive liquidity is undesirable in any business.Because liquidity and liquidity are two faces of the same coin, so it is the concern which decides the adequate liquidity to its concern.

The day to day expenses that is direct and indirect expenses such as purchase of raw material, wages, carriage inward,freight, salary, printing and stationery, postage and telegram, depreciation, interest and sundry expenses etc. are managed with the liquid assets available in the business.If a firm fails to manage its day today expenses then, it badly affects the profitability as well as more functioningof its operations. Therefore adequate liquidity is the need of a business concern.

\section{Review of literature}

Vimla.S Kumar.JP., "An Analysis of Liquidity Management of Select Pharmaceutical Companies in India,the term 'liquidity' refers to the ability of a firm to meet its obligations in the short run usually one year.the liquidity resources of a firm may be kept in various forms: cash in hand and cash at Bank in current assets, reserve drawing power under a cash credit and overdraft arrangement and short term deposits.Cash balances in current account provide the highest degree of liquidity. This study examines how the liquidity position of topfive pharmaceutical companies based on sales. Statistical Techniques like standard deviation co-efficient of variation, and Motaal's test have been employed in order to examine the liquidity position.

Rahul RVaghela, JagdishRRaiyani"., " A Study on Liquidity Management of Selected Automobile Companies in India", aim of the present study is to know overall liquidity of selected automobile companies in India.Tofulfil the purpose of this study secondary data of five years (2014-15 to 2018-19) has been collected from the annual reports and Money control.Liquidity analysis has been done with the help of minimum, maximum, mean, standard deviation, covariance and one-way ANOVA to analyse the collected data and presented in tables.Findings and suggestions are given in the last part of the study.Study concluded that overall study of Hero Motocorp is excellent. Bajaj Auto also has better liquidity.Maruti Suzuki and Mahindra have to make some efforts to improve their liquidity. Tata Motors need to make more efforts to reach the desired liquid level as it does not have sufficient liquidity to meet its short-term obligations.Findings and suggestions for further improvement are given at the end of the study.

ModiVishakhaben", "A Study on Measuring Liquidity of Selected Indian Automobile Companies", the study attempts to measure the liquidity status of selected automobile companies in India.For the study, data were collected from secondary sources such as journal, articles, annual reports, and consolidated financial statements.In this study, in liquid ratio and quick ratio are calculated for the period of five years 2014-15 to 2018-19 to measure the liquidity position of companies.Statistical tools like Mean,Standard Deviation and Coefficient of Variance were used to analyse the data and also use Bar-chart to better understand the comparison of liquidity ratios. This study concluded that Ashok Leyland Limited, Bajaj Auto Limited and Eicher Motors; these automobile companies have a weak liquidity position while on the other hand Hero Motocorp limited has a good liquidity position and the Force Motors Limited has a very much strong liquidity position.

Shiva Kumar, N. Babita Thimmaiah"., "Working Capital Management its Impact on Liquidity and Profitability-A Study of Coal India Limited",the present paper makes an attempt to give a conceptual insight on Working Capital Management and assess its impact on liquidity and profitability of Coal India Limited.The liquidity and profitability trade-off has become an important aspect of for all the organisations. The attempt also has been made to test the liquidity and profitability position.For this correlation and spearman's rank method has been applied.The correlation and spearman's ranking method indicates weak correlation and negative relationship between liquidity and profitability.TheMotaal's test has also been applied to test the liquidity performance.Itindicates liquidity position of the firm has improved overall study period.This study covers five year data from 2010-2011 to 2014-15.For the analysis ratio indicating 
working capital performance and some Statistical Techniques are employed.

VikasGarg,PoojaTewari, Shalini Srivastav,"Liquidity and Profitability Analysis of Selected Automobile Companies", liquidity management and profitability of a firm is of major importance in the current scenario majorly for financial management decision. The most accepted fiscal performance can only be achieved by organisations who can maintain a trade-off between profitability and liquidity position of the organisation.The main objective of the study is to know the importance of both of them.In this regard, researchers are interested in the study of automobile companies. it is known that managers can increase the profitability and sustain liquidity by working on various ratios of the companies like, current ratio, liquidity ratio etc. it can also be emphasize on maintaining the cost of goods sold and analysing the various areas of operations in order to strengthen the financial position of the country.All financial ratios are used to assess the performance of the company but profitability ratios are helpful in calculation of the operations invested.Various liquidity ratios are also calculated for short-term analysis of a business concern.Thus, we can say that profitability ratios are the major decision makers to understand the overall efficiency of an organisation.Management and profitability ratios relating to investment are helpful in calculating a reasonable return on capital.

\section{Research Gap}

The review of literature studied above, depicts that the liquidity resources of a firm are kept in various forms such as Cash, Cash at bank, reserve drawing power under a cash credit and overdraft and short term deposits. The study deals with the liquidity in pharmaceutical company are based on sales.

The other study deals with liquidity analysis with the help of minimum, maximum, mean, standard deviation, covariance and one-way ANOVA to collected data and based on the above analysis it arrived at findings and suggestions in automobile industry with regard to the liquidity analysis.

Another study deals with liquid Assets and liquid liabilities to measure the liquidity position of sample company under the study and other statistical tools like mean standard deviation and coefficient of variance were used to analyse data.Another study deals with Working Capital Managements, its impact on liquidity and profitability. The study deals with liquidity and profitability trade off and it also attempts to test the liquidity and profitability position with the application of correlation and Spearman's rank method. This study also used Motaal's test to assess the liquidity performance.

Another study deals with liquidity and profitability management. study tries to understand a trade-off between profitability and liquidity position. the study focuses on cost of goods sold and analysing various areas of operations in order to strengthen the financial position. The study found out the profitability ratios are the major decision makers to understand the overall efficiency of an organisation.

It can be said that a lot of work have been undertaken on liquidity analysis of steel industry, pharmaceutical industry, automobile industry etc. But, liquidity analysis on sugar industry in Karnataka is scare. Therefore there is a need to undertake a study on the liquidity analysis on sugar industry in Karnataka. The study will deals with size of cash, technical liquidity and solvency current ratio, application of ' $t$ ' test for current ratio and quick ratio are covered in the study.

\section{Statement of the Problem}

The adequate liquidity position of a concern, shows the ability to manage day-to-day operations in the business. The study attempts to evaluate the current assets, current liabilities, liquid assets and liquid liabilities etc. to assess the liquidity position as well as solvency position of select sample sugar factories in Karnataka state. The study is also interested in applying the various statistical tools to arrive at the conclusion.

\section{Objectives of the Study}

- To evaluate the liquidity position of select sample sugar factories in Karnataka state.

- To offer suggestions.

\section{Need for the Study}

As liquidity and solvency position of a business, decides the financial strength of business concern. There is a need to evaluate the liquidity analysis of sample sugar factories in Karnataka state. The study is applying various liquidity ratios and other statistical tools to arrive at meaningful findings and conclusion.

\section{Scope of the Study}

The study covers only select sugar factories in Karnataka and excludes all other public and co-operative sugar factories from the study. At the same time the period is confined to 10 years starting from 2005-2006 to 2014-2015, and the performance of selected factories before and after study period excluded.

\section{Research Design}

The study is nature of desk research.

Sources of Data: The data required for the study collected from secondary source. The secondary data obtained from the Annual reports of the selected factories; magazines, Government reports, newspapers, internet surfing etc.

Sample Design: As on October 2011, the population for the study comprises of 38 private sugar factories in Karnataka. With the use simple random sampling technique the researcher selected10 Sugar factories in the Karnataka State. However due to non-cooperation of two factories (GEM and Jamkhandi Sugars Limited) in providing data they have been out of the study. This leaves eight factories as sample and represents the sugar industry. The sample factories are given below:

1. Parrys Sugars Limited (Parrys)

2. ShriPrabhulingeshwara Sugars And Chemicals Limited (Prabhulingeshwara)

3. Shree Renuka Sugar Limited (Renuka)

4. The Ugar Sugars Works Limited (Ugars)

5. Athani Farmers Sugar Factory Limited (Athani)

6. DavangereSugar Limited (Davangere)

7. Sri Chamundeshwari Sugar Limited (Chamundeshwari)

8. Bannari Amman Sugars Limited (Bannari)

Here on words the sample factories are called in short names.

Tools of Analysis 
The data collected analysed with the help of ratio analysis, trend analysis and statistical techniques wherever necessary to draw meaningful inferences.

\section{Limitations of the Study}

The figures taken from the annual reports have been rounded off to two decimals of rupees in Lakhs. The data available in financial statements have been translated into pre-designed the structure format so that a meaningful interpretation could be made through inter-firm and intra-firm comparison. The format in which data have been classified is selected after careful consideration of the operations of the sugar factories. Nevertheless, the limitations do in No way act as a deterrent in drawing effective and meaningful inferences from this study.

\section{Liquidity Analysis of Sugar Industry}

Cash is the life blood of a business firm. It is needed to acquire supplies, resources, equipment and other assets used in generating the products and services provided by a firm. It is also needed to pay wages and salaries to workers and managers, taxes to government, interest and Principal to creditors and dividends to shareholders. Therefore, cash is medium of exchange which allows management to carry on the various activities of the business form from day to day.

Cash is a non-earning asset so excessive cash balance simply lowers the assets turnover, thereby reducing both the rate of return on net worth and value of the stock.

Why does a firm need cash? As John Maynard Keynes put forth, there are possible motives for holding cash. ${ }^{6}$

- The Transaction Motive - This motive arises due to the necessity of having cash for various disbursements like purchase of raw materials, payment of business expenses, payment of tax, payment of dividend and so on. Hence, some cash balance is required as a buffer.

- The Precautionary Motive - this motive of holding cash requires meeting any contingency in future. It provides a cushion or buffer to withstand some unexpected emergency. To protect it against uncertainties in cash inflows, a firm may require some cash balance.

- The Speculative Motive - this motive of holding cash relates for investing in profitable opportunities as and when they arise. In other words, this motive comes from a desire of holding cash to gain in speculative transactions such as, purchase of raw materials at reduced price on payment of immediate cash, dealing in commodities in bulk purchasing and selling when rates are considered favourable. Hence, firms, which have such speculative dealings, may carry additional liquidity.

The analysis of cash management in sample factories has been carried out by analysis of the size of cash, technical liquidity and solvency (current ratio and quick ratio), actual liquidity and solvency (Net cash flow to current liabilities, coverage of current liabilities) and utilisation of cash resources.

\section{Size of Cash}

No formulae can determine the size of cash of a business enterprise. The optimum cash balance depends on various factors such as the size of the business, credit position of the firm, the manufacturing cycle, the sales and collection cycle and the maturing debts. It also depends on the liquidity of other assets. Liberal maintenance of cash ensures a source of security. A firm should ensure that it does not suffer from lack of liquidity and also it does not carry too much of cash.

Cash occupies an important position in the structure of firm's current assets. Cash enables a firm to pay current obligations as and when they fall due since it forms most liquid assets. The ratio of cash to current assets explains the relationship between cash and current assets. If most of the current assets are made up of cash alone, the profitability of an enterprise decreases, because cash by itself does not yield any profit. Guthman and Dougall opined that in a comfortably managed business, cash probably would not run less than five to 10 Per cent of the current assets. $^{7}$

Table-1 depicts cash and bank balance as a percentage of cash assets in sample factories. Cash and bank balance to current assets on an average, was recorded 6.53 per cent in the consolidated picture. The percentage shows variations, it can be said that there was no stability in the cash position of the industry. As cash balance maintained in all the years except 2007 was ten per cent of total current assets. It shows the inadequacy of cash balance. The overall industry maintained 6.53 per cent of current assets which may be the optimum cash balance.

An analysis of individual factories points out that the average cash balance was inadequately maintained in Chamundeshwari (2.93) per cent, Bannari (3.76) per cent, and Parrys 


\section{Table-1}

\section{Cash and Bank Balance to Current Assets in Sample Sugar Factories}

(`in lakhs)

\begin{tabular}{|c|c|c|c|c|c|c|c|c|c|c|c|}
\hline $\begin{array}{l}\text { Name of the } \\
\text { Factory }\end{array}$ & 2006 & 2007 & 2008 & 2009 & 2010 & 2011 & 2012 & 2013 & 2014 & 2015 & $\begin{array}{c}\text { Averag } \\
\text { es }\end{array}$ \\
\hline \multirow[t]{3}{*}{ Consolidated } & 14074. & 25808 . & 16314. & & 9179.1 & & 8079.2 & 14262. & 16691. & 20341. & 16021.0 \\
\hline & 86 & 96 & 01 & 27 & 2 & 5 & 6 & 75 & 86 & 58 & 4 \\
\hline & 9.44 & 14.31 & 8 & 8 & 2.4 & 8.15 & 4 & 3 & 4 & 4 & 6.53 \\
\hline \multirow[t]{2}{*}{ Parrys } & 838.67 & 927.38 & 668.73 & 559.93 & 312.06 & 875 & 1329.2 & 54.85 & 128.17 & 398.6 & 609.26 \\
\hline & 5 & 10 & 8 & 4.1 & 2 & 4 & 5 & 0.3 & 1 & 2 & 4.14 \\
\hline \multirow{2}{*}{$\begin{array}{l}\text { Prabhulingeshw } \\
\text { ara }\end{array}$} & 330.82 & 505.94 & 287.28 & 266.41 & 556.42 & 1381 & 1614.9 & 1671.9 & 1281.9 & 1000.3 & 889.7 \\
\hline & 3.4 & 7.2 & 3 & 2.4 & 3 & 7 & 6.5 & 5.21 & 5.04 & 3.33 & 4.61 \\
\hline \multirow[t]{2}{*}{ Renuka } & 1716.6 & 3067.1 & 1338.6 & 21028. & 2347.1 & 1039.2 & 0 & 9147.2 & 7096.9 & 9142.1 & 6213.68 \\
\hline & 7 & 9.15 & 3 & 11 & 1.1 & 0.4 & 0 & 3.3 & 5 & 4 & 4.88 \\
\hline \multirow[t]{3}{*}{ Ugar } & 7932.4 & 14729. & 2826.3 & 1926.7 & 2665.1 & 2612.9 & 2693.6 & 1580.5 & 2140.8 & & 2007 ? \\
\hline & 9 & 19 & 8 & 2 & 8 & 1 & 9 & 8 & 2 & 020.21 & 2.02 \\
\hline & 27 & 32 & 10 & 7 & 6.45 & 6.04 & 5.41 & 3.4 & 5 & 2 & 10.43 \\
\hline \multirow[t]{3}{*}{ Athani } & 1091.6 & 44308 & 72171 & 17824 & 1271 & 47034 & 1471.8 & 00265 & 2591.8 & 5062.4 & 130600 \\
\hline & 2 & 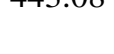 & 121.11 & 170.24 & $12 \%$ & $4 / 0.34$ & 9 & 902.05 & 1 & 1 & 1500.09 \\
\hline & 9 & 3 & 4.4 & 2 & 1 & 2.05 & 8.2 & 4 & 11.12 & 12 & 5.68 \\
\hline \multirow[t]{3}{*}{ Davangere } & 24357 & 05003 & 46303 & 1935.7 & 1760.5 & 16507 & 38331 & 23424 & 2508.9 & 1723.1 & 118720 \\
\hline & & & & 4 & 8 & & & & 3 & 5 & \\
\hline & 3.13 & 11. 24 & 6 & 17.24 & 15.4 & 13.2 & 2 & 2 & 16.84 & 10.52 & 8.63 \\
\hline \multirow{2}{*}{$\begin{array}{l}\text { Chamundeshwa } \\
\text { ri }\end{array}$} & 332.77 & 328.55 & 648.96 & 247.23 & 852.45 & 239.34 & 111.25 & 329.44 & 589.87 & 1114.5 & 479.44 \\
\hline & 3 & 2 & 4 & 2 & 5 & 2 & 1.25 & 2 & 3 & 5 & 2.93 \\
\hline \multirow[t]{3}{*}{ Bannari } & 1588.3 & 4850.7 & 9359.3 & 5407 & 55823 & 48826 & 47502 & 34278 & 35337 & $1080 ?$ & 106460 \\
\hline & 2 & 9 & 2 & 349.1 & 500.25 & 400.20 & 47.02 & 342.10 & & 1000.2 & 1904.00 \\
\hline & 5 & 11.24 & 15.43 & 1.1 & 1.15 & 1 & 1 & 0.4 & 0.3 & 1 & 3.76 \\
\hline
\end{tabular}

Note: Figures in Parentheses Represents Debtors Due Over Six Months as A Percentage of Total Debtors.

Source: i) Appendix-II (A) to II (I) 
(4.14) per cent, as the yearly percentage of cash and bank balances to current assets was below the standard norm of five to 10 per cent with most years of the study in all of above factories. But in Chamundeshwari, it is satisfying to note that the percentage tended to improve over the study period from three Per cent in the initial year (2006) to five per cent by the end of the study period (2015). The cash position of Chamundeshwari, Bannari and Parrys was very tight due to improper cost planning.

The other five factories - Ugars (10.43 per cent), Davangere (8.63 per cent), Athani (5.68 per cent), Shree Renuka (4.88 per cent), and Prabhulingeshwara (4.61 per cent) have carried on with adequate cash and bank balance as their average ratio of cash and bank balance to current assets remained within the norm of five to 10 per cent.

Ugars, Davangere and Athani have experienced wider fluctuations in their cash and bank balances over the study period pointing to their inconsistent cash planning. The theoretical assumption that there should not be significant variations in the cash balance in relation to current assets of an enterprise over the study period of time was not observed in these factories. It is apparent that while there was insufficiency of cash balance in few factories, inconsistency of cash balance maintained was found in some factories. It implies that cash planning was improper in all the sample sugar factories.

\section{Technical Liquidity and Solvency}

Liquidity refers to the ability of a concern to meet its current obligations as and when they are become due. The short-term obligations are met by realising amount from current, floating of circulating assets. The current assets should either be liquid or near liquidity. These should be convertible into cash for paying obligations of short -term nature. The sufficiency or insufficiency of current assets should be assessed by comparing them with current (short term) liabilities. If current assets can pay-off current liabilities, then liquidity position will be satisfactory. On the other hand, if current liabilities may not be easily met out of the current assets then liquidity position will be bad.

Technical liquidity and solvency refers to the firm's ability to meet its short-term obligations out of the realisation of current assets. To test and measure the technical liquidity and solvency of the selected factories, two important ratios are used current ratio and quick ratio.

\section{Current Ratio}

Current ratio shows the relationship between current assets and current liabilities. This ratio is also known as working capital ratio. It is a measure of general liquidity and is most widely used to make the analysis of a short term financial position or liquidity of a firm. The current ratio can be computed as follows

Current Ratio $=$ Current Assets $/$ Current Liabilities

The ideal standard of current ratio is 2:1 for manufacturing concerns. The current ratio is a generally an acceptable measure of short term solvency as it indicates the extent to which clients of short-term creditors are covered by assets.

Table- 2 indicates that the sugar industry possessed,on an average, of 1.12 times current assets for every one rupees of current liabilities. The current ratio was far away from the ideal norm of 2:1 in all sample factories except Bannari. The current ratio had recorded inconsistency. Further, it is evident that the liquidity of the sugar industry was critical and the short term financial strength was not very satisfactory.

Analysis of individual factories demonstrates that Bannari's current ratio on an average had reached the ideal norm of 2:1. In Bannari the current ratio was always greater than Unity in all years of the study under reference. On an average, the ratio was recorded at 2.04 times, which was above the Industry average (1.12 times) and also reached the ideal norm of $2: 1$. It implies that the factory have adequate ability to pay current liabilities from its current assets. In other words, the factory's short term solvency was good. The current ratio was above the standard norm in Chamundeshwari with 3.83 times 3.01 times and 2.49 time in 2006, 2007 and 2009. The current ratio among the factories ranged between the lowest of 0.38 times (2014) in Renuka to the highest of 3.83 times (2006) in Chamundeshwari. In fact, the average current ratio was less than combined average in Renuka (0.92 times) and Prabhulingeshwara (0.91 times). It does not mean that these factories did not possess adequate ability to repay completely the current debt out of the funds realised from current assets. The current ratio of Renuka and Prabhulingeshwara has recorded variations throughout the study period under observation. Hence, the liquidity of these two factories was precarious and threatening. 


\begin{tabular}{|c|c|c|c|c|c|c|c|c|c|c|c|}
\hline \multicolumn{12}{|c|}{$\begin{array}{l}\text { Table-2 } \\
\text { Current Ratio in Sample Sugar Factories } \\
\text { (in Times) }\end{array}$} \\
\hline $\begin{array}{l}\text { Name of the } \\
\text { Factory }\end{array}$ & 2006 & 2007 & 2008 & 2009 & 2010 & 2011 & 2012 & 2013 & 2014 & 2015 & Averages \\
\hline Consolidated & 1.5 & 1.42 & 1.301 & 1.48 & 1 & 1.07 & 1.19 & 0.76 & 0.71 & 0.74 & 1.12 \\
\hline Parrys & 1.22 & 1.18 & 0.86 & 1.11 & 1.27 & 1.82 & 1.39 & 1.2 & 1.7 & 1.21 & 1.3 \\
\hline Prabhulingeshwara & 1.25 & 1.11 & 0.97 & 1 & 0.96 & 0.94 & 0.69 & 0.73 & 0.75 & 0.74 & 0.91 \\
\hline Renuka & 1.26 & 1.13 & 1.18 & 1.54 & 0.85 & 0 & 0.87 & 0.59 & 0.38 & 0.45 & 0.92 \\
\hline Ugar & 1.27 & 1.16 & 1.05 & 1.09 & 1.16 & 1.08 & 1.02 & 1.03 & 1.03 & 0.97 & 1.09 \\
\hline Athani & 1.16 & 1.04 & 1.01 & 1 & 0.97 & 1.15 & 1.14 & 1.22 & 1.16 & 1.21 & 1.11 \\
\hline Davangere & 1.54 & 1.48 & 1.5 & 1.48 & 1.75 & 1.63 & 1.36 & 0.93 & 1.87 & 1.4 & 1.5 \\
\hline Chamundeshwari & 3.83 & 3.01 & 1.52 & 2.49 & 1.43 & 1.71 & 0.71 & 0.99 & 0.96 & 0.96 & 1.76 \\
\hline Bannari & 2.4 & 2.6 & 2.41 & 1.94 & 1.74 & 2.13 & 1.82 & 1.64 & 1.86 & 1.83 & 2.04 \\
\hline
\end{tabular}

Student ${ }^{6} \mathrm{t}$ test has been applied to test the hypothetical

Source:i) Appendix-II (A) to II (I)

ii) Appendix-III (A) to III (I)

The current ratio was less than the ideal norm of 2:1 and higher than or marginally equal to the unity in all the sample factories of the study under reference in Parrys, Ugars, Athani, Davangere and Chamundeshwari on an average basis with 1.3 times, 1.09 times 1.11 times, 1.5 times and 1.76 times respectively. It implies that these factories short term solvency was better than Renuka and Prabhulingeshwara.

The overall liquidity of the sample factories was not up to the mark as these factories did not have adequate quantum of current assets to liquidate the currently maturing obligations except Bannari on an average basis. current ratio of 2:1 and the details of which are furnished in Table3 . The calculated value of ' $t$ ' is greater than the table value of ' $t$ ' at five per cent level of significance except in Chamundeshwari and Bannari. Hence in the sugar industry in Karnataka state, the hypothetical current ratio does not hold well. In the case of individual factories also same observation is found except in Chamundeshwari and Bannari. In other words ' $t$ 'test confirms the observation already made.

In case of Chamundeshwari and Bannari the calculated value of ' $t$ ' is less than the table value of ' $t$ ' 'at five per cent level of significance. Therefore it can be said that the hypothetical current ratio hold well in Chamundeshwari and Bannari.

\begin{tabular}{|c|c|c|c|c|c|c|c|c|c|}
\hline \multicolumn{10}{|c|}{$\begin{array}{l}\text { Table-3 } \\
\text { Application of ' } t \text { ' test for Current Ratio }\end{array}$} \\
\hline Particulars & $\begin{array}{l}\text { Consolidate } \\
\text { d }\end{array}$ & $\begin{array}{l}\text { Parry } \\
\text { S }\end{array}$ & $\begin{array}{l}\text { Prabhulingeshwa } \\
\text { ra }\end{array}$ & $\begin{array}{l}\text { Renuk } \\
\text { a }\end{array}$ & $\begin{array}{l}\text { Uga } \\
\mathbf{r}\end{array}$ & $\begin{array}{l}\text { Athan } \\
\text { i }\end{array}$ & $\begin{array}{l}\text { Davanger } \\
\text { e }\end{array}$ & $\begin{array}{l}\text { Chamundeshwa } \\
\text { ri }\end{array}$ & $\begin{array}{l}\text { Bannar } \\
\text { i }\end{array}$ \\
\hline $\begin{array}{l}\text { Mean of } \\
\text { current } \\
\text { Ratio }\end{array}$ & 1.12 & 1.3 & 0.91 & 0.92 & 1.09 & 1.11 & 1.5 & 1.76 & 2.04 \\
\hline SD & 0.284 & 0.277 & 0.175 & 0.457 & $\begin{array}{l}0.08 \\
4\end{array}$ & 0.087 & 0.239 & 0.976 & 0.312 \\
\hline Value of ' $t$ ' & 9.295 & 7.581 & 18.686 & 7.089 & 32.5 & 30.69 & 6.276 & 0.738 & 0.385 \\
\hline $\begin{array}{l}\text { Table } \\
\text { Value of } t \\
\text { at } 5 \% \text { level } \\
\text { of } \\
\text { significanc } \\
\text { e }\end{array}$ & 2.262 & 2.262 & 2.262 & 2.262 & $\begin{array}{l}2.26 \\
2\end{array}$ & 2.262 & 2.262 & 2.262 & 2.262 \\
\hline
\end{tabular}

Note:i) No. of observations in each case are 10.

ii) Hypothetical ratio is 2:1 For all sample factories

iii) Degree of Freedom (N-1) or (10-1) for all the sample factories

Source: Computed From Table 6.18

\section{Quick Ratio}

Quick ratio, is also known as acid test or liquid ratio, is a more rigorous test of liquidity than the current ratio. The term 'liquidity' refers to the ability of a firm to pay its short-term obligations as and when they become due. Quick ratio may be defined as the relationship between quick or liquid Assets and current liabilities. An asset is said to be liquid if it can be converted into cash within a short period without loss of value. In that sense, cash in hand and cash at Bank are the most liquid assets. The Other assets which can be included in the liquid assets are bills receivable, sundry 
debtors, marketable securities and short term or temporary investment. Inventories and prepaid expenses cannot be termed to be liquid assets because they cannot be converted into cash immediately without a sufficient loss of value. The quick ratio can be computed as follows:

$$
\text { Quick Ratio }=\frac{\text { Quick Assets(Current Assets-Inventory) }}{\text { Current Liabilities }}
$$

Quick ratio is shown in Table-4. The quick ratio, on an average, worked out to 0.46 times in the consolidated position. Combined average had marginally improved. Current liability could not be repaid completely out of quick assets. In other words, the sugar industry had been exposed to critical state of working capital condition.

Average Ratio was less than the standard norm of 1:1 in all the sample factories with an exception of Chamundeshwari (1.35 times). The liquidity position was good in these two factories. In other factories, the ratio recorded less than the standard norm. It indicates that the claims of short-term creditors were not at all protected and they were exposed to greater risk.

It may be deduced that with the exception of Chamundeshwari, all other sample factories were subject to poor liquidity. The shortterm financial strength of the factories was unfortunately critical. In just, these factories were technical insolvent. The trends in current ratio and quick ratio are also shown in Figure.6.8.

\section{Table-4}

Quick Ratio in Sample Sugar Factories (in Times )

\begin{tabular}{|l|l|l|l|l|l|l|l|l|l|l|l|}
\hline $\begin{array}{l}\text { Name of the } \\
\text { Factory }\end{array}$ & $\mathbf{2 0 0 6}$ & $\mathbf{2 0 0 7}$ & $\mathbf{2 0 0 8}$ & $\mathbf{2 0 0 9}$ & $\mathbf{2 0 1 0}$ & $\mathbf{2 0 1 1}$ & $\mathbf{2 0 1 2}$ & $\mathbf{2 0 1 3}$ & $\mathbf{2 0 1 4}$ & $\mathbf{2 0 1 5}$ & $\begin{array}{l}\text { Average } \\
\text { s }\end{array}$ \\
\hline Consolidated & 0.77 & 0.75 & 0.66 & 0.72 & 0.43 & 0.38 & 0.32 & 0.18 & 0.18 & 0.18 & 0.46 \\
\hline Parrys & 0.53 & 0.96 & 0.58 & 0.7 & 0.63 & 0.84 & 0.56 & 0.11 & 0.57 & 0.3 & 0.58 \\
\hline $\begin{array}{l}\text { Prabhulingeshwar } \\
\text { a }\end{array}$ & 0.33 & 0.32 & 0.22 & 0.23 & 0.15 & 0.37 & 0.14 & 0.18 & 0.2 & 0.17 & 0.23 \\
\hline Renuka & 0.72 & 0.79 & 0.77 & 0.76 & 0.4 & 0 & 0.31 & 0.16 & 0.13 & 0.14 & 0.46 \\
\hline Ugar & 0.75 & 0.54 & 0.37 & 0.37 & 0.26 & 0.21 & 0.15 & 0.09 & 0.18 & 0.08 & 0.3 \\
\hline Athani & 0.3 & 0.17 & 0.21 & 0.31 & 0.23 & 0.26 & 0.23 & 0.24 & 0.39 & 0.35 & 0.27 \\
\hline Davangere & 1.27 & 0.72 & 0.82 & 0.82 & 0.84 & 0.91 & 0.98 & 0.28 & 0.9 & 0.57 & 0.81 \\
\hline Chamundeshwari & 3.47 & 2.48 & 1.21 & 2.2 & 1.1 & 1.13 & 0.33 & 0.5 & 0.47 & 0.64 & 1.35 \\
\hline Bannari & 0.94 & 1.18 & 1.18 & 0.84 & 0.79 & 0.79 & 0.35 & 0.28 & 0.15 & 0.21 & 0.67 \\
\hline
\end{tabular}

Source:i) Appendix-II (A) to II (I)

ii) Appendix-III (A) to III (I)

\section{Findings of the study}

- An analysis of cash and bank balance to current assets as a percentage shows that cash balance position was inadequately maintained in three sugar factories namely Parrys, Chamundeshwari and Bannari. The average ratio of cash and bank balance to current assets in these three factories was below the standard normal of 5 to 10 percent. The three factories namely Prabhulingeshwara, Renuka and Athani had maintained their cash and balance at comfortable position. The cash balance of Ugars and Davangere is highest among all other sample sugar factories. But, all the sample factories did not maintain their cash balances at a consistent level since the Percentage share of cash balance to current assets varied widely.

- The overall liquidity of sample sugar factories was not up to the mark, the overall liquidity of sample sugar factories was not satisfactory on consolidation basis and analysis of individual factory reveals that the Bannari had its current ratio of 2.04 Times of its current liabilities followed by Chamundeshwari and Davangere had 1.76 and 1.5 times of its current liabilities respectively. Other than these above three factories, the liquidity position of Parrys, Prabhulingeshwara, Renuka, Ugars and Athani had revealed that their current assets and current liabilities are as per standard norms with minor 
appreciation in fractional values of current assets.

- The quick ratio on an average of consolidation basis is satisfactory. But, the individual factories revealed that the quick assets of Prabhulingeshwara are inadequate to pay the claims of short term debt. On the other hand, the Chamundeshwari and Davangererevealed that ratio of quick assets to current liabilities which is above the standard norms. The Parrys, Renuka, Ugars, Athani and Bannari revealed that their quick assets are as per standard norms which are quite better as compared to other factories within the sample sugar factories.

\section{SugGestions FOR THE StUdy}

- Analysis of cash and bank balance to current assets reveals many of the sample factoriesmaintained inadequate cash balance. This should be completely eliminated, as it would cause many other problems. To regularise and optimise the use of cash balances, proper methods such as cash planning, forecasting and controlling may be adopted. Excess cash balance, if any, has to be invested in short-term marketable securities. To find out excess or inadequate cash balances, weekly, monthly and quarterly cash budget needs to be prepared and reviewed.

- In order to strengthen the liquidity position, it is necessary for some of the sample factories to strengthen the quality and quantity of current assets. Further, longterm funds have to be used to finance core current assets. It is better if the company can reduce the over-sized short-term loans and advances.

- The practice of diversion of working funds for financing long-term assets shall altogether be stopped. This will help in improving the working capital condition of the factories. In fact, the generation of internal funds through fair profit performance and their diversion for current assets financing ensures strong liquidity of the sample factories.

- The sample factories are desperate need of financial support from commercial banks to augment their working capital funds. Commercial banks ought to provide working capital funds liberally at concessional rates of interest at least for a temporary period to tide over the present working capital crisis. Return on investment in the sugar industry has shown a declining trend. Shooting prices of inputs have put a severe strain on the sugar industry resulting in the inflated operating ratio. Therefore, the need of the hour is the effective control of operating costs. Adoption of profit planning and control techniques such as marginal costing, cost-volume-profit analysis, standard costing, activity based costing And flexible budgetary control system may enable the factories to push down the operating costs and boost up the profits.

\section{CONCLUSION}

The sample factories did not maintain consistent cash balance. It may be due to improper cash planning. The overall liquidity of the sample factories was not up to the mark as these factories did not have adequate quantum of current assets to liquidate current maturing obligations.

In case of Parrys the liquidity position was precarious and threatening. Indeed, this factory is in need of adequate working capital funds. In all the years, with an exception of last two years of the study, the sugar industry was able to liquidate its currently maturing obligations to the extent of 13 per cent with cash flows generated internally. It indicates that the sample factories were not able to liquidate their maturing obligations completely with the cash flow generated internally.

Cash was well controlled in the sample factories as their operations enabled them to make more sales. The abnormally high cash turnover is an indicative of the indulgence of the factories in over-trading.

\section{REFERENCES}

[1] Vimla.S Kumar.JP., “ An Analysis of Liquidity Management of Select Pharmaceutical Companies in India, Global Journal for Research Analysis, Vol-5, issue-12, Dec 2016,Pp.27-30.

[2] Rahul RVaghela, JagdishRRaiyani., " A Study on Liquidity Management of Selected Automobile Companies in India", ShodhSarita, Vol-6, Issue-23, July-Sept2019, Pp259-264.

[3] Modi Vishakhaben, "A Study on Measuring Liquidity of Selected Indian Automobile Companies", International Journal of Science and Research, Vol-9, Issue-5, May 2020,Pp.330-332.

[4] Shiva Kumar, N. BabitaThimmaiah., " Working Capital Management its Impact on Liquidity and Profitability-A Study of Coal India Limited", International Journal of Research- Granthaalayah, Vol-4, Issue-12, Dec 2016, Pp.178-187.

[5] VikasGarg,PoojaTewari, ShaliniSrivastav, "Liquidity and Profitability Analysis of Selected Automobile Companies", International Journal of Supply Chain Management, Vol-7 Issue- 4, Aug 2018, Pp.101-110.

[6] Keynes, J.M., The General Theory of Employment, Interest on Money, New York: Harcourt Brace Jovanovich, Inc., 1956, Pp. 170-174. (Reproduced In G. Sudarsana Reddy, "Financial Management Principles And Practices", Himalaya Publishing House, First Edn, 2008, P. 446-447).

[7] Guthaman, H.G. And Dougall, H. E.,Corporate Financial Policy, New York: Prentice-Hall, 1955, P.85.

\section{AUTHORS}

First Author - Dr.Salma Banu, Assistant Professor, Dept of Commerce \&amp; Management, UCA, TUT 
